\title{
Economic Analysis of Market Performance of Fresh Fish in Lagos State, Nigeria
}

\author{
Foluso Osundare and Taiwo Adedeji
}

\begin{abstract}
Department of Agricultural Economics and Extension Services, Faculty of Agricultural Sciences, Ekiti State University, AdoEkiti, Nigeria
\end{abstract}

\begin{abstract}
This study analysed the market performance of fresh fish marketing in Lagos state, Nigeria. It critically focused on ascertaining the market structure, determining the profitability of fish marketing and determining the marketing efficiency of fresh fish marketing in the study area. Multistage sampling procedure was used to sample 80 fresh fish marketers from Lagos state. The data collected for the study were analysed using Gini coefficient, budgetary technique and shepherd efficiency model. The study revealed that there was inequality in the income distribution among the fresh fish marketers with Gini coefficient of 0.78 , it further shows that fresh fish marketing is profitable with gross margin of \#27,101.36 and that fish marketing activities among fish marketers is highly efficient (517.5\%). Thus, government should help in the provision of a soft loan to the marketers so as to promote fresh fish marketing being a profitable and efficient business.
\end{abstract}

Keyword- Market Performance, Market Structure, Profitability, Market Efficiency.

\section{INTRODUCTION}

Fish marketing is a primordial economic activity in Nigeria (Agbebi, 2010). Its activities cover both the coastal and inland waterways and it was of tremendous economic value to the pre-colonial Nigerians (Ehinmore, 2007). Although, fresh fish were said to be marketed mostly in short distance areas owing to the perishable nature attached to it.

Fish is a major source of animal protein and an essential food item in the diet of many Nigerians, being relatively cheaper than meat. Accordingly, agricultural production and fish marketing must develop hand in hand because they are partners in a progressive system (Iliyasu, Onu, Midau and Fintan, 2011).

Assessment of how well the process of marketing is carried out, and according to Awol (2010) performance is how successfully its aims are accomplished. Is produce assembled and delivered on time and without wastage? Is it well packed and presented attractively? Is its quality reliable and are contract kept? Is the consumption of the products increasing and sales in competitive market expanding? There are such many practical indications of how well a certain marketing system is operating.

Also, the form in which markets are structure is almost assumed to rigidly determine each firm's conduct (output decisions and pricing behaviour), which yields an industry's overall performance (e.g. its efficiency and profitability) (Umoinyang, 2014).

Meanwhile, to be more profitable, fish trade requires every activity that increases sales revenue and as well decreasing the costs of marketing, thus profitability of fish is the measure of fish profit against its power to earn profit (Monica, 2014).

An efficient marketing system ensures that goods which are seasonal will be available all year round, with little variation in prices, which can be attributed to cost of marketing functions like storage, processing, transportation(Nwaru, Nwosu and Agummuo,2011).Thus, marketing efficiency increases with continued transitions and specialized functions like wholesale and retail (Enete, 2008). This supported the claim ofAdegeye and Dittoh (1985) that the general-purpose of marketing efficiency is to provide goods to consumers in the required form at the required time and place with the lowest possible marketing costs consistent with the interests of the producers.

An extensive literature survey has been carried out on economic analysis of fresh fish marketing performance with empirical evidence from many studies and special attention paid to the market structure, profitability and factors influencing it and the efficiency of fish marketing. Evidence from Adeleke and Afolabi, (2012) and Edward and Madugu, (2011)have established the profitability and marketing efficiency of fresh fish marketing. Also, Bukenya, Theodora, Twinamasiko and Molnar. (2012) and Abdal and Eglal, (2010), in their study, assert that fish marketing profitability is eminent with high market performance. However, the scholars' works on the, performance of fresh fish marketing in Nigeria are still limited. Thus, this study seeks to explore the performance of fresh fish marketing by ascertaining the market structure, determine the profitability, efficiency of fresh fish and 
estimate factors influencing the income of fresh fish marketers in the study area.

\section{METHODOLOGY}

\section{The Study Area, Sampling Technique and Data Collection}

This study was carried out in Lagos State, located within the southwest Nigeria. Farming is part of the notable occupation of the people most especially along the coast as well as other related activities.

Multistage sampling procedure was used for this study which involves purposive selection of Lagos State in the first stage being one of the notable fishing states in Nigeria, purposive selection of two Local Government Areas (LGA's) namely Ibeju-Lekki and Ikorodu LGA's because of the prevalence of fresh fish marketers in the area. In the third stage, two communities were selected using purposive sampling technique. The selected communities are Orimedu and Otto in Ibeju-lekki and Ijede and Ipakodo in Ikorodu local government respectively. In the last stage, ten fresh fish marketers were selected from each of the four communities using snowball sampling technique. Thus, a total of 80marketers/respondents were used for this study. Structured questionnaire were administered and responses were analyzed using descriptive statistics, Gini coefficient, budgetary techniques and shepherd index.

\section{Analytical techniques}

The data obtained from the respondents were subjected to descriptive and inferential statistics. Inferential statistics such as Gini coefficient was used to ascertain the market structure of fresh fish marketing, budgetary technique was employed to ascertain the profitability of fresh fish marketing and shepherd index was used to determine the marketing efficiency of fresh fish marketing in the study area.

\section{Model Specification}

Gini Coefficient: The Gini coefficient mathematically, it is explicitly represented by

$\mathrm{GC}=1-\sum\left[\mathrm{X}_{\mathrm{t}-1} * \mathrm{Y}_{\mathrm{t}-1}\right]$

Where:

$\mathrm{N}=$ is the number of elements (observations)

$\mathrm{X}=$ Proportion of Fresh fish seller

$\mathrm{X}=$ Proportion of fish seller is given as $\mathrm{X}=$ No of fish seller in a market

$\overline{\text { overall No of fish Marketers under study }}$

$\sigma \mathrm{X}\left(\mathrm{X}_{\mathrm{t}-1}\right)=$ Cumulative Proportion of fish sellers $(\mathrm{X})$

$\mathrm{Y}=$ Proportion of total sales by Fresh fish marketer

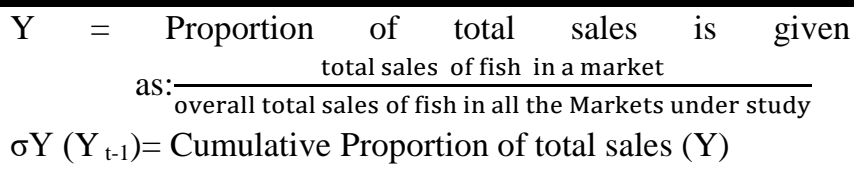

Budgetary Technique: The budgetary technique encompasses the analyses of the gross margin which involves the cost and return analysis of fish marketing in the study area. The gross margin formula is explicitly stated below:

The budgetary technique involves the cost and return analysis of fish marketing in the study area. It is explicitly stated as:

$\mathrm{G} . \mathrm{M}=\sum\left(\mathbf{P}_{\mathrm{ij}} \mathbf{Q}_{\mathrm{ij}}-\mathbf{r}_{\mathrm{ij}} \mathbf{X}_{\mathrm{ij}}\right)$

$\mathbf{P}_{\mathbf{i j}}=$ Price of fish in $\mathrm{i}^{\text {th }}$ for $\mathrm{j}^{\text {th }}$ respondent.

$\mathbf{Q}_{\mathrm{ij}}=$ Quantity of fish in $\mathrm{i}^{\text {th }}$ for $\mathrm{j}^{\text {th }}$ respondent.

$\mathbf{r}_{\mathrm{ij}}=$ Price of Variable Input in $\mathrm{i}^{\text {th }}$ for $\mathrm{j}^{\text {th }}$ respondent.

$\mathbf{X}_{\mathrm{ij}}=$ Quantity of Variable Input in $\mathrm{i}^{\text {th }}$ for $\mathrm{j}^{\text {th }}$ respondent.

The profitability and efficiency ratio was calculated as follows:

Profitability ratio is given as: $\frac{\pi}{T V C}$

Efficiency ratio is given as: $\frac{T R}{T V C}$

a. $\frac{T R}{T V C}>0=\mathrm{It}$ is operational efficiency

b. $\frac{T R}{T V C}<0=$ It is operational inefficiency

c. $\frac{\pi}{T V C}>0=$ It is profitable

d. $\frac{\pi}{T V C}<0=$ It is not profitable

Thus, the values in the Profitability and Efficiency ratio were computed in the marketing of fish in the study area.

Where:

$\prod=$ Profit

$\mathrm{TR}=$ Total Revenue

TVC $=$ Total Variable Cost

\section{Multiple Regression Model}

Multiple regression is one of the analytical tools that are used to determine the effect(s) of one or more variables on another. The marketing function postulated for fresh fish trader's annual income in the study area is implicitly presented by $\mathrm{Y}=\mathrm{f}\left(\mathrm{X}_{1}, \mathrm{X}_{2}, \mathrm{X}_{3}, \mathrm{X}_{4}, \mathrm{X}_{5}, \mathrm{X}_{6}, \mathrm{u}_{\mathrm{i}}\right)$ as shown below:

Where $\mathrm{Y}=$ Annual Income from Fish Marketing (

$\mathrm{X}_{1}=$ Age of respondents (years)

$\mathrm{X}_{2}=$ Fish Marketing experience (years)

$\mathrm{X}_{3}=$ Number of year spent in school (year)

$\mathrm{X}_{4}=$ Cost of purchase ( $\left.\mathrm{N}\right)$

$\mathrm{X}_{5}=$ Cost of transportation (

$\mathrm{X}_{6}=$ Membership of association $(\mathrm{Yes}=1, \mathrm{No}=0$ )

$\mathrm{X}_{7}=$ Price per $\mathrm{kg}$ of fish ( $)$

$\mathrm{X}_{8}=$ Quantity of Fish Sold $(\mathrm{Kg})$ 
Shepherd efficiency models: The Shepherd efficiency models developed by Shepherd, (1965) and used by Massoud and Gowda, (2012) was used to analyze the marketing efficiency of fish marketing by estimating as follows:

Marketing cost: The total marketing cost was determined by the following formula:

$\mathrm{TC}=\mathrm{C}_{\mathrm{P}}+\sum \mathrm{Mci}$

Where:

$\mathrm{i}=1$

TC $=$ Total Cost of Marketing

$\mathrm{C}_{\mathrm{p}}=$ Producer cost of marketing

$\mathrm{Mc}_{\mathrm{i}}=$ Marketing cost by the ith trader

Marketing margin: The absolute margins of both the processed and unprocessed fish retailers were determined as follows:

$\mathrm{AM}=\mathrm{Psa}-(\mathrm{Pba}+\mathrm{Mc})$

$\mathrm{AM}=$ Absolute Margin

Psa $=$ Selling price

$\mathrm{Pba}=$ Buying price

Mc $=$ Marketing cost

Producer's share in the consumer price: The producer' share in the consumer price was calculated by the following indicator:

$$
P s=\frac{P p}{P r} \times 100
$$

Ps $=$ Producer' share in the consumer price

$\mathrm{Pp}=$ Producer' price

$\operatorname{Pr}=$ Retail price or final consumer price
Marketing efficiency with Shepherd Index proposed to evaluate the marketing efficiency of fish marketing activities. It is given by:

$$
M E=\frac{P r}{T C+A M}
$$

$\operatorname{Pr}=$ Retail price or final consumer price

$\mathrm{TC}=$ Total Cost of Marketing

$\mathrm{AM}=$ Absolute Margin

$$
\begin{array}{cc}
\text { Value added by Marketing } & M E= \\
\frac{\text { Marketing cost or cost of markeying services }}{\text { M }} & \times 100
\end{array}
$$

$\operatorname{Pr}=$ Retail price or final consumer price

$\mathrm{TC}=$ Total Cost of Marketing

$\mathrm{AM}=$ Absolute Margin

\section{RESULTS AND DISCUSSION}

\section{Market Structure}

The Gini coefficient of 0.78 was revealed (Table 1), indicated high level of inequality distribution of sales income for fresh fish market in the study area. This was in line with Dillion and Hardaker (1993) in their finding that the value of Gini coefficient greater than 0.35 is high indicating inequitable distribution of sales income/sales.

This was evidenced with the total income generated from total sales at $\$ 17,914,000$ while $82.5 \%$ and the remaining $17.5 \%$ of the total sales contributed $\$ 10,964,000$ and N6,950,000respectively. This deduces that only $17.5 \%$ of the respondents played an active role in the market while

\begin{tabular}{|c|c|c|c|c|c|c|c|c|c|c|}
\hline Income & $\begin{array}{l}\text { No of } \\
\text { sellers }\end{array}$ & $\%$ & $\begin{array}{l}\text { Cum } \\
\%\end{array}$ & $\begin{array}{l}\text { Propo } \\
\text { rtion } \\
\text { of } \\
\text { seller } \\
\mathrm{s}(\mathrm{X})\end{array}$ & $\begin{array}{l}\text { Cum } \\
\text { ulativ } \\
\text { e } \\
\text { propo } \\
\text { rtion } \\
\text { of } \\
\text { seller } \\
\text { s }\end{array}$ & $\begin{array}{l}\text { Total } \\
\text { sales }\end{array}$ & $\begin{array}{l}\text { Cum Total } \\
\text { Sales }\end{array}$ & $\begin{array}{l}\text { Pro } \\
\text { port } \\
\text { ion } \\
\text { of } \\
\text { total } \\
\text { sale } \\
\text { s } \\
(Y)\end{array}$ & $\begin{array}{l}\text { Cumul } \\
\text { ative } \\
\text { propor } \\
\text { tion of } \\
\text { total } \\
\text { sales }\end{array}$ & $\mathbf{X Y}$ \\
\hline$<150,000$ & 39 & 48.75 & 48.75 & 0.49 & 0.49 & $5,133,000$ & $5,133,000$ & 0.29 & 0.29 & 0.141375 \\
\hline $150,001-250,000$ & 17 & 21.25 & 70 & 0.21 & 0.7 & $2,761,000$ & $7,894,000$ & 0.15 & 0.44 & 0.031875 \\
\hline $250,001-350,000$ & 10 & 12.50 & 82.5 & 0.13 & 0.83 & $3,070,000$ & $10,964,000$ & 0.17 & 0.61 & 0.0215 \\
\hline $350,001-450,000$ & 5 & 6.25 & 88.75 & 0.06 & 0.89 & $2,020,000$ & $12,984,000$ & 0.11 & 0.72 & 0.006875 \\
\hline $450,001-550,000$ & 5 & 6.25 & 95 & 0.06 & 0.95 & $2,450,000$ & $15,434,000$ & 0.14 & 0.86 & 0.00875 \\
\hline $550,001-650,000$ & 3 & 3.75 & 98.75 & 0.04 & 0.99 & $1,780,000$ & $17,214,000$ & 0.1 & 0.96 & 0.00375 \\
\hline$>650,000$ & 1 & 1.25 & 100 & 0.01 & 1 & 700,000 & $17,914,000$ & 0.04 & 1 & 0.0005 \\
\hline Total & 80 & 100 & & & & $\begin{array}{l}\text { 17,914,00 } \\
0\end{array}$ & & & & 0.214625 \\
\hline
\end{tabular}
majority $(82.5 \%)$ of the respondents have low funding for their marketing activities in the study area.

Table.1: Computation of Gini Coefficient for Fresh Fish Market Structure in the Study Area

Source: Analysis of Field Survey 2017 
Using the formula, Gini-Coefficient $(\mathrm{GC})=1-\sum \mathrm{XY}$

Fresh Fish Market Structure: $\mathrm{GC}_{\mathrm{F}}=1-0.214625$

$$
=\mathbf{0 . 7 8 5 3 7 5}
$$

\section{Profitability Analysis}

The measure of the cost and return analysis of the marketers in the study area was carried out using the budgetary technique. The result in Table 2 showed that the cost of purchase gulped up to $91.97 \%$ of the total variable cost for the fresh fish marketers. Also, the table revealed that a marketer earned average revenue of $\$ 223,925.00$ but incurred a total variable cost of $196,466.73$ over the same period. This indicates that an average marketer earned N27,458.28 as gross margin per year suggesting that fresh fish marketing is a profitable venture in the study area. This is evident in the study of Adeleke and Afolabi, (2012) which indicates that fresh fish marketing is a profitable venture. The result of the profitability ratio or the return on investment (ROI) was 0.14 indicating that for every 1.00 spent on fresh fish marketing14kobo is gained by the marketers.

Table.3: Computation of cost and return analysis of the fresh fish marketers

\begin{tabular}{|c|c|c|}
\hline Item & Cost ( & $\%$ TVC \\
\hline Cost of purchase & $14,455,638$ & $91.97 \%$ \\
\hline Transportation & $5,76,500$ & $3.67 \%$ \\
\hline Labour & 8,800 & $0.05 \%$ \\
\hline Bowl & 186,000 & $1.18 \%$ \\
\hline Bracket & 0 & $0.00 \%$ \\
\hline Wire gauze & 0 & $0.00 \%$ \\
\hline Knife & 33,000 & $2.09 \%$ \\
\hline Salting & 0 & $0.00 \%$ \\
\hline Association fee & 3,150 & $0.02 \%$ \\
\hline Storage & 154,500 & $0.98 \%$ \\
\hline Rent (Space and others) & 272,250 & $1.73 \%$ \\
\hline Security & 16,000 & $0.10 \%$ \\
\hline Utility & 11,500 & $0.07 \%$ \\
\hline Total TVC & $15,717,338$ & $100 \%$ \\
\hline Average TVC & \multicolumn{2}{|c|}{$196,466.73$} \\
\hline Total Revenue & \multicolumn{2}{|c|}{$17,914,000$} \\
\hline Gross Margin (TR-TVC) & \multicolumn{2}{|c|}{$2,196,662$} \\
\hline Average GM & \multicolumn{2}{|c|}{$27,458.28$} \\
\hline Profitability ratio & \multicolumn{2}{|c|}{0.14} \\
\hline
\end{tabular}

Source: Analysis of Field Survey 2017

\section{Income Determinants of Fresh Fish Marketing}

The estimate of the factors influencing the income of the marketers in the study area was carried out using the multiple regression analysis. Three functional forms of regression analysis (Table 3) were undertaken to determine the model that best fits the data with respect to coefficient of determination, $F$ statistics and the t-value of the marketers.

The regression results show that, linear functional form had the highest $\mathrm{R}^{2}$ (i.e. coefficient of multiple determination) of $58.1 \%$ and was chosen as the lead equation. The regression results show that, the regressors combined are responsible for $58.1 \%$ of the variation in income due to these factors incorporated in the model. The remaining $41.9 \%$ are caused by other factors not included in the model. The entire equation measured by the F-ratio (11.981) is significant at $5 \%$ probability level. Regression result shows that, the cost of purchase $\left(\mathrm{X}_{4}\right)$ is positively significant at $1 \%$ while the number of years spent in school $\left(\mathrm{X}_{3}\right)$ and price of fish $\left(\mathrm{X}_{7}\right)$ are also significant and positive at $5 \%$ and $1 \%$ levels respectively. The implication of this is that a unit increase in cost of purchase, price of fish and number of years spent in school would lead to increase in the annual income of marketers. The positive coefficient of number of years spent in school also suggests that literate marketers may be more enterprising than their illiterate counterparts probably because of their ability to use market information to an advantage which gave credence to the findings of Adeleke and Afolabi, (2012)

Also, the marketing experience $\left(\mathrm{X}_{2}\right)$, cost of transportation $\left(\mathrm{X}_{5}\right)$ and membership of association $\left(\mathrm{X}_{6}\right)$ positively and significantly influenced the income of fresh fish marketers in the study area, which indicates that an increase in these variables resulted in an increase in income of fish marketers. This implies that marketing experience, cost of transportation and membership of association are significant determinants of the income in the study area.

However, the age of the marketers negatively affected the income marketers with t-value of -1.065 , which indicates that increase in age resulted in decrease in income of fish marketers. This might be due to the strength required in the marketing of fish. This is supported by the findings of Bassey, Okon, Ibok and Umoh, (2013) that age negatively but significantly influenced the profit of fish marketers.

Also, quantity of fish sold negatively affected the income of the marketers. This is an indication that an increase in the quantity marketed of fresh fish reduces income. This might be probably because the more the quantity of fresh fish in market, the less the marketing price probably because of the perishable nature of fresh fish. 
Table.3: Computation of multiple regression analysis of the marketers

\begin{tabular}{|c|c|c|c|}
\hline & Linear & Semi-Log & Double-Log \\
\hline Variable & $\begin{array}{c}\text { Coefficient } \\
\text { (t-value in parenthesis) }\end{array}$ & $\begin{array}{c}\text { Coefficient } \\
\text { (t-value in parenthesis) }\end{array}$ & $\begin{array}{c}\text { Coefficient } \\
\text { (t-value in parenthesis) }\end{array}$ \\
\hline Constant & $\begin{array}{c}-351119.373 \\
(-1.450)\end{array}$ & $\begin{array}{c}10.520 \\
(12.790)\end{array}$ & $\begin{array}{c}-.404 \\
(-.089)\end{array}$ \\
\hline Age (X1) & $\begin{array}{c}-3231.459 \\
(-1.065)\end{array}$ & $\begin{array}{c}-.014 \\
(-1.359)\end{array}$ & $\begin{array}{c}-.751 \\
(-1.747) \\
\end{array}$ \\
\hline Marketing Experience (X2) & $\begin{array}{c}4441.984 \\
(.749)\end{array}$ & $\begin{array}{l}.004 \\
(.214)\end{array}$ & $\begin{array}{l}.079 \\
(.653)\end{array}$ \\
\hline $\begin{array}{l}\text { No of YearsSpent in School } \\
\text { (X3) }\end{array}$ & $\begin{array}{c}13985.915^{* *} \\
(2.602)\end{array}$ & $\begin{array}{c}.025 \\
(1.368)\end{array}$ & $\begin{array}{l}.062 \\
(.545)\end{array}$ \\
\hline Cost of Purchase (X4) & $\begin{array}{l}.633 * * * \\
(8.381)\end{array}$ & $\begin{array}{l}1.67 \mathrm{E}-006 \\
(6.496) * * *\end{array}$ & $\begin{array}{l}.326 * * * \\
(5.225)\end{array}$ \\
\hline Cost of Transportation (X5) & $\begin{array}{c}.158 \\
(.267) \\
\end{array}$ & $\begin{array}{c}9.64 \mathrm{E}-007 \\
(.481) \\
\end{array}$ & $\begin{array}{c}.010 \\
(.188)\end{array}$ \\
\hline $\begin{array}{l}\text { Membership of Association } \\
\text { (X6) }\end{array}$ & $\begin{array}{c}22244.821 \\
(.454)\end{array}$ & $\begin{array}{l}.086 \\
(.515)\end{array}$ & $\begin{array}{l}.003 \\
(.011)\end{array}$ \\
\hline Price of fish (X7) & $\begin{array}{c}617.897 * * * \\
(3.158)\end{array}$ & $\begin{array}{l}.002 * * * \\
(3.267)\end{array}$ & $\begin{array}{c}1.832 * * * \\
(2.953)\end{array}$ \\
\hline Quantity of fish sold (X8) & $\begin{array}{l}-64.057 \\
(-1.642)\end{array}$ & $\begin{array}{c}-5.78 \mathrm{E}-005 \\
(-.436)\end{array}$ & $\begin{array}{l}-.162 * * \\
(-2.464)\end{array}$ \\
\hline $\mathrm{R}^{2}$ & 0.581 & 0.481 & 0.386 \\
\hline SE & 137891.60 & 0.46487 & 0.51134 \\
\hline $\mathrm{F}$ & 11.981 & 7.993 & 5.261 \\
\hline
\end{tabular}

Source: Analysis of Field Survey $2017 * * *$ Significantat $1 \% * *$ significant at $5 \%$ and ${ }^{*}$ significant at $10 \%$

\section{Marketing Efficiency of Fresh Fish}

Results in Table 4 show that, efficiency figure is far greater than $100 \%$ (i.e. $517.0 \%$ ) whereas an efficiency ratio of $100 \%$ (or 1.0) indicative of efficient trading/marketing activities. Thus, fish marketing activities among fresh fish marketers is highly efficient. The result also, indicate that an increase in the cost of performing marketing service by 100 percent will give a more than proportionate increase of 417.0 percent in the level of satisfaction derived from a kilogram of fresh fish sold in the market.

Table.4: Computation of marketing efficiency of fresh fish marketing

\begin{tabular}{|l|c|}
\hline Efficiency Variables & Fresh Fish \\
\hline Total Cost of Marketing & \\
\hline Cost of Produce & $14,455,638$ \\
\hline Transportation & 576,500 \\
\hline Labour & 8,800 \\
\hline Bowl & 186,000 \\
\hline Bracket & 0 \\
\hline Wire gauze & 0 \\
\hline Knife & 33,000 \\
\hline
\end{tabular}

\begin{tabular}{|l|c|}
\hline Salting & 0 \\
\hline Association fee & 3,150 \\
\hline Storage & 154,500 \\
\hline Rent & 272,250 \\
\hline Security & 16,000 \\
\hline Utility & 11,500 \\
\hline Marketing cost by ith trader & $1,261,700$ \\
\hline Total Cost of Marketing & $\mathbf{1 5 , 5 3 1 , 3 3 8}$ \\
\hline Absolute margin & \\
\hline Selling Price (Ps) & $17,914,000$ \\
\hline Total cost of marketing (Mc) & $15,531,338$ \\
\hline Buying Price (Pb) & $14,455,638$ \\
\hline & $\mathbf{- 1 2 , 0 7 2 , 9 7 6}$ \\
\hline Producer Share & \\
\hline Price of buying fish & $14,455,638$ \\
\hline Price of selling fish & $17,914,000$ \\
\hline Producer share & 0.80 \\
\hline Percentage of Producer share & $80 \%$ \\
\hline Marketing Efficiency & \\
\hline ME & 5.17 \\
\hline ME\% & $517.0 \%$ \\
\hline
\end{tabular}

Source: Analysis of Field Survey 2017 


\section{CONCLUSION}

The study showed that more female $(81.25 \%)$ and more (90\%) youth within the age bracket of 21-50 years with majority $(57.5 \%)$ of married are involved in fresh fish marketing. There was an uneven distribution of income in the market with majority (82.5\%) of fish marketers having low funding for their marketing activities with very high (0.78) Gini coefficient value. It further revealed that an average gross margin of \#27,458.28 implying that fresh fish marketing was profitable. The marketing efficiency of $571.14 \%$ was revealed indicating a high efficiency. It is recommended that government should encourage marketers in the business by giving them soft loans.

\section{REFERENCES}

[1] Abdal A. E. and Eglal A. S., (2010).Economics of Fish Production and Marketing: A Case Study of Khartoum State, Sudan: Journal of Applied Sciences Research, 6(10): 1533-1538

[2] Adegeye, A. J. and Dittoh, J. S. (1985).Essentials of agricultural economics. Ibadan: Impact Publishers pp. 113-116.

[3] Adeleke, M. L., Afolabi, J.A., (2012). Appraisal of Fresh Fish Marketing in Ondo State, Nigeria: IIFET Tanzanian Proceedings

[4] Agbebi, F. O., (2010). Salient Issues In Fish Marketing System In Nigeria. Department of Forestry, Wildlife and Fisheries Management University of Ado Ekiti, Ado-Ekiti,Ekiti State, Nigeria, Journal of Environmental Issues and Agriculture in Developing Countries Vol. 2 No. 1,

[5] Awol, E. (2010). Status of Avocado Production in Kenya.Kenya Agricultural Research Institute, Nairobi, Kenya.

[6] Bassey NE, Okon UE, Ibok OW, Umoh IU (2013): Comparative Analysis of the Economics of Aquacultural Fish Production in Some Parts of South South Nigeria. ARPN Journal of Agriculture and Biological Science.2013c; 8(8): 587-595.

[7] Bukenya J. O., Theodora Hyuha, Julius Twinamasiko and Joseph Molnar (2012). "Economics of Fish Marketing in Central Uganda: A Preliminary Analysis". Selected Paper prepared forpresentation at the Southern Agricultural Economics Association Annual Meeting, Birmingham, AL, February 4-7

[8] Edward, A. and A. J. Madugu, (2011). Marketing and distribution channel of processed fish in Adamawa State, Nigeria. Global journal of management and business research. 11(4) 21-26.
[9] Ehinmore, O.M (2007).Fishing in South-Western Nigeria in the $19^{\text {th }}$ Century: A Study of the Ilaje Fishing Economy. African Studies Review, 1(1), 56.

[10] Enete, A. A. (2008). Vertical differentiation of cassava marketing channels in Africa. TROPICULTURA. 26 (4) $206-210$.

[11] Iliyasu, A.H., J.I. Onu, A. Midau and J.S. Fintan, (2011). Economics of smoked and dried fish marketing in Yola North and South local Government areas of Adamawa State, Nigeria. J. Agric. Soc. Sci., 7: $13-16$

[12]Monica, T., (2014).Profitability Analysis (A comparative study of SAIL \& TATA Steel).IOSR Journal of Economics and Finance Vol. 3(2) pp. 19-22

[13] Nwaru, J. C., A. C. Nwosu and V. C. Agummuo (2011).Socio-economic determinants of profit in wholesale and retail banana marketing in Umuahia agricultural zone of Abia State, Nigeria. Journal of sustainable development in Africa. 13(1) 200-210.

[14] Okeke J.J. , Okoye C.O. , Ayadiuno R.U. , Nwosu M.C. , Ibemenuga K.N. , Arazu V. N.(2018), Evaluation of the Ichthyofaunal Diversity of Some Sections of Omambala, Ezu and Ahommiri Rivers in Anambra State, Nigeria. International Journal of Forest, Animal And Fisheries Research (IJFAF), 2(1) 18-27.

[15] Umoinyang, M.E. (2014): Economics of Fish Marketing in Akwalbom State, Nigeria. MSc. Thesissubmitted to the department of agricultural economics, UNN. 